\title{
Resenha do título brasileiro Ecumenismos e pentecostalismos: a relação entre o pescoço e a guilhotina? (2018).
}

Review of the Brazilian title Ecumenismos and pentecostalismos: the relation between the neck and the guillotine? (2018).

\section{Reseña del título brasileño Ecumenismos y pentecostalismos: la relación entre el cuello y la guillotina? (2018).}

Graham Gerald McGeoch*

RESUMO
ALENCAR, Gedeon Freire de. Ecumeninsmos e pentecostalismos: a relação entre o pescoço e a gui-
lhotina? São Paulo: Recriar, 2018, 220 p.

ABSTRACT

ALENCAR, Gedeon Freire de. Ecumeninsmos e pentecostalismos: a relação entre o pescoço e a guilhotina? [Ecumenism and Pentecostalism: the relationship between the neck and the guillotine?]. São Paulo: Recriar, 2018, 220 p.

RESUMEN

ALENCAR, Gedeon Freire de. Ecumeninsmos y pentecostalismos: a relação entre o pescoço e a guilhotina? [Ecumenismos y pentecostalismos: la relación entre el cuello y la guillotina ?]. São Paulo: Recriar, 2018, 220 p.

Gedeon Alencar tem escrito um livro em tom polêmico e acerbo, e tanto o mundo pentecostal quanto ecumênico deveriam alegrarem-se com a iluminação e intuição que ele traz ao estudo.

O livro é fruto de uma inquietação: porque os ecumenismos são antipentecostais e os pentecostalismos são antiecumêncicos? (p. 19). Quando Alencar passa de forma rápida pela questão da ditadura militar (1964-1985), acho que ele apresenta a possibilidade de uma chave de leitura das igrejas brasileiras sobre a questão. A pena é que ele não se detém numa análise mais profunda deste período histórico em relação a auto-compreensão teológica e política dos pentecostalismos e ecumenismos no Brasil.

Professor doutor da Faculdade Unida, Vitória/ES. 
O livro apresenta os dois mundos - ecumenismos e pentecostalismos - como universos paralelos notando que o Conselho Mundial de Igrejas nasce em 1948 enquanto a Conferência Mundial Pentecostal nasce em 1947. Apenas em 2010, o secretário-geral do CMI é convidado para palestrar na CMP (p. 97). Desde a virada do milênio, há aproximações frutíferas entre pentecostalismos e ecumenismos na sua expressão institucional. Porém, como Alencar bem sabe tanto pentecostalismos quanto ecumenismos são muito mais que expressões institucionais.

O grande valor do livro é de trazer ao conhecimento público brasileiro o trabalho da Comissão Internacional do Diálogo Católico [Romano]-Pentecostal. Como nota Alencar, "A CIDCP é desconhecida no Brasil porque poucos falam dela" (p. 107). Isso apesar de mais de 40 anos de trabalho com textos publicados! Alencar gasta apenas 10 páginas introduzindo esta 'joia-rara'. Merece muito mais pesquisa tanto das ciências sociais quanto da própria teologia. Alencar e outros podem e devem falar mais para ampliar o conhecimento público, e especificamente o conhecimento nas igrejas pentecostais e católica romana sobre este trabalho e diálogo teológico.

Em duas coisas, não estou convencido pelo texto de Alencar. Primeiro, ele é sociólogo tratando de teologia. O texto sempre fala da Igreja Católica quando na verdade ele se refere à Igreja Católica Apostólica Romana. No mundo da teologia, e em tratar um tema com sensibilidades eclesiológicas, é fundamental de especificar as diferenças entre Igreja Católica e Igreja Católica Apostólica Romana ou Igreja Católica Romana.

Segundo, a leitura que ele faz apresentando o movimento ecumênico representado pelo CMI como sendo fruto de eurocentrismos ou de WASPS - White Anglo-Saxon Protestants - e WASPS liberais por cima (!) não reflete a catolicidade do movimento. Por exemplo, WASPS liberais não articulam nem expressam a compreensão Ortodoxa, nem das igrejas africanas dos ecumenismos. E ausenta-se na leitura do Alencar o grito fundamental dos ecumenismos ecoando desde a Ásia proveniente do V.S. Azariah na Conferência Mundial Missionário em Edimburgo em 1910 - deem-nós amigos! Ademais o texto não faz uma clara distinção entre ecumenismo do CMI e da Igreja Católica Romana. Não são as mesmas propostas.

Aliás, o texto não esclarece entre ecumenismo do CMI e o pan-Protestantismo do CMP, e por sinal, do Pacto de Lausane (onde participou Antônio Gilberto, teólogo de referência para as Assembleias de Deus no Brasil (p. 73)). Pan-Protestantismo também é ecumenismo, ainda de forma limitada! E o exemplo relatado por Alencar de um encontro ecumênico entre Bispo Manuel Ferreira da Assembleia de Deus e Reverendo Moon da Coreia pa- 
rece piada. Nem o CMI, nem a Igreja Católica Romana considerariam isso um encontro ecumênico. Acho tampouco os pentecostalismos. Alencar tem que esclarecer os termos do debate com mais nitidez. Tal clareza ajudaria compreender melhor a proposta ecumênica dos pentecostalismos. Como o livro nota, com o surgimento do Forum Cristão Mundial se tem outras propostas de ecumenismos onde os pentecostalismos engajam de forma mais expressiva, sim.

Alencar deveria ser parabenizado pelo livro polêmico e acerbo. Ele abre novos horizontes para futuras pesquisas e arrisca provocar os ecumenismos e pentecostalismos com perguntas incômodas. A Editora Recriar deveria ser parabenizado por oferecer este joia-raro ao público brasileiro. Há alguns erros no texto, principalmente na bibliografia, mais não distraí do conteúdo central do livro. Recomendo e espero encontrar este livro em bibliografias básicas de cursos de Teologia e Ciências das Religiões e em bibliotecas de igrejas e de pessoas pentecostais e ecumênicos, além de interessados(as) na questão de religião no Brasil. O livro pode ser uma divisor de águas na pesquisa e compreensão do tema no Brasil.

Submetido em: 9-4-2019

Aceito em: 11-6-2019 